УДК: 330: 519.876 .3658

https://doi.org/10.29038/2786-4618-2021-01-161-174

PhD in Economics, Associate Professor,
Kyiv National Economic University named after Vadym Hetman,
Mathematical Modeling and Statistics Department,
Kyiv, ORCID ID: 0000-0001-5262-856X
e-mail: tatyanakmytuk@gmail.com
Inna Shatarska,
senior lecturer
Kyiv National Economic University named after Vadym Hetman,
Mathematical Modeling and Statistics Department,
Kyiv, ORCID ID: 0000-0001-7070-9718
e-mail: inna_shatarskaja@ukr.net
Tetiana Bilyk,
PhD in Economics, Associate Professor,
Kyiv National Economic University named after Vadym Hetman,
Mathematical Modeling and Statistics Department,
Kyiv , ORCID ID: 0000-0002-4059-8794
e-mail: bitetiana@gmail.com

\title{
AN INTEGRATED APPROACH TO LOGISTIC RISK ASSESSMENT
}

The article considers theoretical and methodological aspects of logistics, namely logistics processes, logistics chain, logistics system, logistics management, logistics risk. A method of logistics management as an integrated process using the so-called network planning is proposed. This method allows a systematic approach to planning and managing the process of developing a new complex system. The process itself is seen as a single, inseparable process of interdependent operations aimed at achieving the ultimate goal. When analyzing the network model, a quantitative assessment of the time and cost of work performed. Elements of risk management in the logistics of enterprises using qualitative and quantitative analysis are considered.

Key words: logistics, risk, critical path method (CPM), program evaluation and review technique (PERT), logistics chain, critical activity, network planning, qualitative and quantitative risk assessment.

Кмытюк Татьяна, кандидат экономических наук, доцент, Киевский национальный экономический университет имени Вадима Гетьмана, кафедра математического моделирования и статистики, г. Киев

Шатарська Инна, старший преподаватель, Киевский национальный экономический университет имени Вадима Гетьмана, кафедра математического моделирования и статистики, г. Киев

Билык Татьяна, кандидат экономических наук, доцент, Киевский национальный экономический университет имени Вадима Гетьмана, кафедра математического моделирования и статистики, г. Киев

\section{КОМПЛЕКСНЫЙ ПОДХОД К ОЦЕНКЕ ЛОГИСТИЧЕСКОГО РИСКА}


В статье рассматриваются теоретические и методологические аспекты логистики, а именно логистические процессы, логистическую цепь, логистическая система, управление логистикой, логистичекий риск Предложенный метод управления логистикой, как сложного процесса, с помощью так называемого сетевого планирования. Этот метод позволяет систематически подходить к планированию и управлению процессом разработки новой сложной системы. Сам процесс рассматривается как единый, неразрывный процесс взаимосвязанных операций, направленных на достижение конечной цели. При анализе сетевой модели производится количественная оценка времени и стоимости выполненной работы. Рассмотрены элементы управления рисками в логистике предприятий с использованием качественного и количественного анализа.

Ключевые слова: логистика, риск, метод критического пути, метод оценки и анализа программ, логистическая цепочка, критическая деятельность, сетевое планирование, качественная и количественная оценка рисков.

Кмитюк Тетяна, кандидат економічних наук, доцент, Київський національний економічний університет імені Вадима Гетьмана, кафедра математичного моделювання та статистики, м. Київ

Шатарська Інна, старший викладач,

Київський національний економічний університет імені Вадима Гетьмана, кафедра математичного моделювання та статистики,

м. Київ

Білик Тетяна, кандидат економічних наук, доцент, Київський національний економічний університет імені Вадима Гетьмана, кафедра математичного моделювання та статистики, м. Київ

\section{КОМПЛЕКСНИЙ ПІДХІ ДО ОЦІНЮВАННЯ ЛОГІСТИЧНОГО РИЗИКУ}

В статті розглянуто теоретичні та методологічні аспекти основних концепцій логістики, а саме логістичні процеси, логістичний ланцюг, логістична система, управління логістикою, логістичний ризик. Запропоновано для аналізу виконання комплексу складних робіт у відповідний термін, коли необхідно пов'язати виконання робіт між багатьма виконавцями за часом, вартістю, ресурсами, іншими техніко-економічними показниками здійснювати за допомогою планування та управління в спеціальній економіко-математичній моделі мережевого планування. Описано два методи, що відображають проекти як мережі діяльності через мережеві діаграми, такі як метод критичного шляху (CPM) та техніка оцінки та огляду програми (PERT).

Класифіковано фактори та чинники ризику в логістиці, розглянуті чинники та фактори логістичного ризику. Систематизовано логістичні витрати, як одні з основних видів логістичних ризиків. Використовуючи дану систему класифікації логістичних витрат можна більш детально проводити якісний аналіз ризику конкретної логістичної системи. Визнено розрахунок параметрів мережевої моделі, які проводяться для повних шляхів, подій і робіт. При аналізі мережевої моделі з оцінкою часу подій та робіт, знайдено найбільш доцільні засоби досягнення оптимальних термінів виконання комплексу робіт, при цьому в першу чергу в мережевому плануванні розраховані критичні робот, проводилася кількісна оцінка часу та вартості виконаної роботи. Наголошено на доцільності використання комплексного підходу щодо аналізу та управління ризиками в логістиці підприємств, а саме: якісний аналіз ризику та кількісний аналіз ризику.

Ключові слова: логістика, ризик, метод критичного шляху, техніка оцінки та аналізу програми (PERT), логістичний ланцюг, критична діяльність, мережеве планування, якісне та кількісне оцінювання ризику. 
Formulation of the Scientific Problem and its Significance. In modern conditions of economic development, logistics is becoming increasingly important, its efficiency depends on the structure of logistics networks. Logistics covers market research and forecasting, production planning, purchase of raw materials and equipment, includes inventory control and a series of sequential operations of goods movement, the study of customer service.

This is the main purpose of logistics: looking for the most efficient ways of transportation and storage, as well as the most profitable ways of marketing, it gives the manufacturer the opportunity to invest in product improvement and depreciation of production.

Despite the fact that the use of logistics in the economy of Ukraine is due to modern realities, the management of enterprises on the basis of logistics approaches is still given insufficient attention compared to developed countries. Improving the management of business structures in modern business conditions requires the solution of a number of tasks, the most important of which are the systematization and generalization of knowledge about the functioning of enterprises on the basis of logistics.

Analysis Research on this Problem. Foreign scientists M.Christopher, B. Fahimnia, R. Molaei, G. C Dias, C. T. Hernandez, Oliveira U., S. Alper, M. Tekin,. and ukrainians O. Zavytiy, T. Didorenk, L, Kondriuk, O.P. Chukurna etc. have explored theoretical and methodological principles of logistic risk in their works. In spite of a big amount of scientific works in this area, assessment of logistic risk basis on the set of qualitative and quantitative methods of economic and mathematical modeling are still poor studied.

The aim of the Article. The purpose of this article is to to reveal the role of logistics management in the development of enterprises at risk on the basis of a set of qualitative and quantitative methods of economic and mathematical modeling.

The Main material Research and Study of Scientific Results.

Logistics processes, the main purpose of which is to move the material flow are provided by a variety of integrated infrastructure designed to perform the following tasks:

- storage of products in special tanks and structures;

- movement of products by means of vehicles and handling vehicles;

- protection of products using warehouses, which requires packaging systems, information transfer, etc;

- transformation of information of logistics processes [1].

The set of logistics processes forms a logistics chain that helps to understand the essence of logistics management.

The logistics chain is a linearly ordered set of participants in the logistics process, which carry out logistics operations to bring external material flow from one logistics system to another in terms of production consumption or to the final consumer in terms of personal non-production consumption.

The general scheme of the logistics chain is expressed by the following sequence of elements (links) of logistics management supplier - manufacturer - intermediary (wholesaler) - intermediary (retailer) consumer.

A logistics system (LS) is a network of organizations, people, activities, information, and resources involved in the physical flow of products from supplier to customer. The logistics system may consist of three main networks or subsystems [2].

The set of links, the boundaries of functioning (at the micro or macro level) and the tasks of the functioning of the LS are combined with the internal goals of the enterprise with external ones.

The need to study the logistics system is due to the potential opportunities to improve the efficiency of economic systems, which carries a logistical approach to the management of material resources (flows and stocks).

Thus the following logistic competitive advantages of firm are allocated:

- the most successful choice of contractors for business relations (suppliers, creditors, commercial intermediaries, as well as consumers;

- selection of optimal distribution channels;

- possibility of modeling of logistics systems and chains; labor);

- creating conditions for resource conservation in all economic flows (material, information, financial,

- combination of economic interests of all participants of logistics systems and others. 
According to the Council of Supply Chain Management Professionals (CSCMP), logistics management is the part of supply chain management that plans, implements, and controls the efficient, effective forward and reverse flow and storage of goods, services, and related information between the point of origin and the point of consumption in order to meet customers' requirements.

Logistics management should be based on the general theory of management in combination with the theoretical and methodological essence of logistics. The object of management is material flows that spread in the markets of goods, services and financial assets, and the subject - the optimization of processes that shape the interaction of economic flows, micro- and macroeconomic systems. The most important principle that logistics management must meet is systemicity and complexity. Therefore we can tell that logistical management is system where subjects of movement of the goods and communication between them are defined. In turn, the logistical connection is a combination of functions of the enterprises, each of which actually keeps the autonomy which allows to estimate really scales of activity of the enterprise. This form is the most adequate in the modern economy, characterized by the collapse of traditional rigid structures of trade, the loss of the usual landmarks of development.

Among the main advantages of logistics management is that the risk associated with the activities of the enterprise is reduced, but it does not relate to technological and political risks. It is due to various market fluctuations (changes in the strategy of suppliers and consumers, the emergence of new competitors), which have a significant impact on risks.

In solving the problem of risk, information support is of paramount importance, which reduces the level of uncertainty and allows to justify a decision. An enterprise that seeks to maintain and increase competitiveness must be open to information coming from the external environment, especially to information of strategic importance. At the same time, it is necessary to take measures to hide one's own information, which is important for competitors.

Analysis of the implementation of a set of complex works in the appropriate time, when it is necessary to link the performance of work between many performers in time, cost, resources, other technical and economic indicators is carried out through planning and management in a special economic and mathematical model of network planning.

Network planning (or project networking) is a generic name for methods that study projects as a set of interconnected activities with the purpose of assisting in planning, managing and controlling projects [3]. Network planning methods are modern analytical methods of planning and management of complex enterprises, ideas, projects and other implementations. There are basically two methods that describe projects as activity networks through network diagrams, such as the critical path method (CPM) and the program evaluation and review technique (PERT). They are largely similar, in particular both methods use a graphical presentation of the project, which represents the project network. CPM is a project analysis technique used to predict total project duration. CPM method is used in cases where the duration of each activity in the project is known and can be determined and added in calculation. Based on duration of each activity, the time needed to complete the overall project is calculated. PERT method is applied when individual activity duration is unknown and cannot be clearly determined. In this case, duration of each individual activity is estimated as: optimistic time, pessimistic time and most likely time, which serves to calculate duration of all activities in the project. PERT is a project network analysis technique used to estimate project duration when there is a high degree of uncertainty with individual activities during estimation [4].

The development of the logistics network itself should be based on three goals - minimizing costs, maximizing capital and maximizing customer service.

The main purpose of the analysis of the network diagram with an estimate of time of events and works consists in finding the most expedient means of achievement of optimum terms of performance of a complex of works, thus first of all in network planning attention is paid to critical activity.

Increasing or decreasing the duration of critical activity and the critical path can lead to a change in the completion date of the complex as a whole.

To perform the planned set of works in the planned time, it is necessary not only to link this term with the one calculated on the basis of the network graph with the allocated labor and material resources, but also to organize the work in such a way that the network plan becomes a reality. 
But quite often there is a problem that companies spend a lot of time and cost to "optimize" only one element of the network, not noticing the negative consequences of costs that may be elsewhere. That is why there is a possibility of conflict as a result of failure to achieve the goals, in particular due to the loss of customers; adjustment of routes, change of place of delivery, etc., which leads to various logistical risks.

Thus, logistics helps to find and implement the optimal ratio of costs, inventory and quality of service. To do this, multivariate calculations are performed, the optimal of which is the one that provides the greatest benefit to the system as a whole with the lowest cost, i.e. with the least risk.

The term "risk" is used in many ways and has is given different definitions depending on the field and context. In general, risk can be defined as the chance of loss or an unfavorable outcome, associated with an action.

Logistics risks are the risks of performing logistics operations of transportation, warehousing, cargo handling and inventory management and the risks of logistics management at all levels, including management risks that arise when performing logistics functions and operations [5].

There are many risks of logistics activities. It is very important that these risks are predicted, detected and taken precautions. Risk factors can be classified in logistics, in particular:

- volume and range of stocks in production, sales, supply;

- number of consumers, factories, suppliers, distribution centers, retail outlets and other facilities;

- location of facilities and designation of service areas;

- loyalty of objects, degree of performance of contracts and frequency of failures;

- damage to stocks during storage and transportation;

- delays in the processes of transportation, production and administration;

- fiscal fees: tax, customs, social;

- systematic risks: inflationary, economic, demographic, environmental, geopolitical;

- actions of competitors;

- investments in logistics, the state of logistics infrastructure;

- specialization of logistics facilities by types of products, operations, customers, suppliers;

- after-sales warranty and service;

- waste disposal, etc.

Risks in logistics can come from internal and external factors.

Internal (endogenous) factors include technological risks of performing such logistical functions as storage, transportation, sorting and aggregation of tangible and intangible flows.

The level of risk in performing these functions is associated with the production potential and organization of technological operations of acquisition, sorting, pre-sales training, the level of subject and technological specialization, the availability of qualified administrative and production staff, cooperative relations, safety, etc.

External (exogenous) factors include risks to which the logistics system is open. External systems include a group of enterprises in the industry, transport, financial, demographic, geopolitical systems and consumer preferences. [6]

These are, for example, the volume of demand, shortage of stocks in the warehouse due to vehicle delays, shutdowns, inflation, competition, political and economic crises, environmental requirements, customs benefits, most-favored-nation treatment, the ability to operate in free economic zones, change in the tax policy of the state.

We propose to divide the sources of logistics risk into three basic classes:

- resources,

- processes of physical development of the system over time,

- managerial influences.

There are all kinds of economic risk in the process of making long-term, medium-term and short-term decisions in logistics:

- business risk arises when designing the logistics structure, the level of coverage of demand areas and is manifested in investment risk when opening facilities, the formation of working capital; 
- economic and managerial risk arises in the process of operation of the logistics system and is manifested in conflict situations with trade unions, emergency failures of the logistics system in the implementation of contracts by contractors;

- commercial risk arises, for example, in the management of pricing, inventories, deferred demand and supply to order;

One of the main types of logistics risks are logistics costs. All components of logistics costs can be conditionally constant or variable. They are included into the total conditional fixed or variable costs of the firm in the calculation of the critical volume of production (volume of production in kind or in cash, the implementation of which covers both fixed and variable costs, but no profit) (table 1).

\section{Logistics costs}

\begin{tabular}{|c|c|}
\hline $\begin{array}{l}\text { Logistics cost } \\
\text { group }\end{array}$ & The composition of logistics costs \\
\hline Supply costs & $\begin{array}{l}\text { - losses on procurement market research; } \\
\text { - maintenance costs of supplier staff; } \\
\text { - entertainment expenses and travel expenses of supply employees; } \\
\text { - costs caused by delays in production due to supply; } \\
\text { - the cost of receiving products and preparing them for industrial consumption; } \\
\text { - costs of submitting and placing orders, concluding contracts; } \\
\text { - costs of maintaining contacts with suppliers; } \\
\text { - costs of selection and evaluation of suppliers; } \\
\text { - costs of monitoring compliance with the terms of supply contracts }\end{array}$ \\
\hline $\begin{array}{l}\text { Costs of } \\
\text { organization } \\
\text { and } \\
\text { management of } \\
\text { production }\end{array}$ & $\begin{array}{l}\text { - R\&D costs, design and technological preparation of production; } \\
\text { - costs for re-adjustment of equipment and its downtime due to poor production } \\
\text { management; } \\
\text { - replacement costs; } \\
\text { - costs for technical quality assurance of products; } \\
\text { - the cost of scheduling production; } \\
\text { - costs of internal relocations; } \\
\text { - cost of defective products; } \\
\text { - costs for waste disposal and utilization. }\end{array}$ \\
\hline $\begin{array}{l}\text { Distribution } \\
\text { costs }\end{array}$ & $\begin{array}{l}\text { - costs of consumer market research; } \\
\text { - costs of maintaining contacts with the consumer; } \\
\text { - costs of processing consumer orders; } \\
\text { - entertainment and travel expenses of sales staff; } \\
\text { - costs of paying for the services of trade intermediaries; } \\
\text { - costs of pre-sale and after-sales service; } \\
\text { - costs for the organization of reverse material flows; } \\
\text { - fines for consumers for late delivery of products; } \\
\text { - losses in sales due to non-fulfillment of customer orders. }\end{array}$ \\
\hline $\begin{array}{l}\text { Transportation } \\
\text { costs }\end{array}$ & $\begin{array}{l}\text { - costs associated with the preparation of products for shipment (checking the } \\
\text { quantity, quality, labeling, packaging); } \\
\text { - costs of loading and unloading; } \\
\text { - payment of the cost of transportation of products to third parties; } \\
\text { - costs of fuel, lubricants, electricity from travel operations; } \\
\text { - costs for maintenance and repair of rolling stock; } \\
\text { - costs of maintaining drivers; } \\
\text { - depreciation of rolling stock; } \\
\text { - costs for the maintenance of production and technical base and infrastructure of } \\
\text { various modes of transport; } \\
\text { - goods insurance costs; } \\
\text { - payment of customs tariffs, taxes and fees during the crossing of the customs }\end{array}$ \\
\hline
\end{tabular}




\begin{tabular}{|l|l|}
\hline & border. \\
\hline $\begin{array}{l}\text { Costs of } \\
\text { maintaining } \\
\text { warehouses and } \\
\text { storage }\end{array}$ & - the cost of stocks; \\
- rent for warehouse space; \\
- costs for the protection of warehouses; \\
- operating costs (electricity, heat and water supply, maintenance); \\
- depreciation of warehouse buildings and equipment; \\
- maintenance costs of warehouse staff; \\
- costs of quantitative and qualitative acceptance of products; \\
- costs of operations with packaging and wrapping; \\
- losses from storage of stocks (damage to products, deterioration, depreciation, \\
write-offs, natural damage, theft); \\
- interest rates on bank loans; \\
- costs of product acquisition; \\
- costs associated with a shortage of stocks (non-receipt of sales revenue, additional \\
costs caused by delays in production, penalties imposed for failure to deliver \\
products to customers, etc.) \\
- costs of immobilization of funds in stocks. \\
\hline $\begin{array}{l}\text { Costs of } \\
\text { maintaining the } \\
\text { support } \\
\text { subsystem }\end{array}$ \\
$\begin{array}{l}\text { - maintenance costs of employees who manage logistics processes; } \\
\text { - payment for consulting services of third-party organizations for logistics } \\
\text { management; } \\
\text { - costs related to office work (office, postal, operation of organizational and } \\
\text { computer equipment, communications, etc.) } \\
\text { - depreciation of computers, office equipment, premises and equipment; } \\
\text { - maintenance costs of administrative premises; } \\
\text { - costs of training logistics staff at all levels. }\end{array}$ \\
\hline
\end{tabular}

Remark:: Compiled by the authors according to the materials [7,8]

It is possible to conduct a detailed qualitative risk analysis of a particular logistics system, given the increase in certain costs as one of the types of risk, using this system of classification of logistics costs.

Regarding quantitative risk analysis, it should be remembered that the quantitative measure of risk is a kind of "vector", the components of which reflect different facets of risk and are formed depending on the objectives of the study, available information, attitudes of risk subjects to uncertainty and conflict.

Therefore, there may be several approaches to assessing the extent of logistical risks. We propose to analyze the logistics system as a logistics network - a complex of certain works, and use a system of quantitative assessments of the degree of risk of the expected result of management.

The notations used are

$(\mathrm{i}, \mathrm{j})=$ Activity with tail event $i$ and head event $j$

$T_{i}^{E}=$ Earliest occurrence time of event $i$

$T_{j}^{L}=$ Latest allowable occurrence time of event $j$

$t_{i j}=$ Estimated completion time of activity $(i, j)$

$T_{i j}^{E S}=$ Earliest starting time of activity $(i, j)$

$T_{i j}^{E F}=$ Earliest finishing time of activity $(i, j)$

$T_{i j}^{L S}=$ Latest starting time of activity $(i, j)$

$T_{i j}^{L F}=$ Latest finishing time of activity $(i, j)$

Critical event - The events with zero slack times are called critical events.

Critical activity - The activities with zero total float are known as critical activities. In other words an activity is said to be critical if a delay in its start will cause a further delay in the completion date of the entire project.

Critical path - The sequence of critical activities in a network is called critical path. The critical path is the longest path in the network from the starting event to ending event and defines the minimum time required to complete the project 
Time $T$ of performance of a complex of works is the minimum time necessary for performance of all elementary works.

The earliest starting time of activity $(i, j)$ coincides with the earliest time of event:

$$
T_{i j}^{E S}=T_{i}^{E}
$$

The earliest start time of the activity is the earliest possible time of starting that activity on the condition that all the other activities preceding to it were began at the earliest possible times. It is the maximum of the earliest finish times of all activities ending in to that event i.e.

$$
T_{i j}^{E S}=\max \left(T_{i j}^{E F}\right) \quad \text { or } \quad T_{i j}^{E S}=\max \left(T_{i}^{E}+t_{i j}\right)
$$

The earliest finish time of an activity is the earliest possible time of completing that activity; equals to the earliest start time for the activity plus the time required to complete the activity. It is given by the formula:

$$
T_{i j}^{E F}=T_{i}^{E S}+t_{i j}
$$

The latest finish time of activity $(i, j)$ is equal to the latest time of event.

$$
T_{i j}^{L F}=T_{j}^{L}
$$

The Latest finish time of activity: is the latest possible time of completing that activity on the condition that all the other activities succeeding it are carried out as per the plan of the management and without delaying the project beyond the stipulated time. It is the minimum of the latest start time of all activities originating from that event i.e.

$$
T_{i j}^{L F}=\min \left(T_{j}^{L S}\right) \quad \text { or } \quad T_{i j}^{L F}=\min \left(T_{j}^{L}-t_{i j}\right)
$$

The latest start time of an activity is the latest possible time of beginning that activity; equal to the latest finish time minus the time required to complete the activity. It is given by the formula

$$
\mathrm{T}_{\mathrm{ij}}^{\mathrm{LS}}=\mathrm{T}_{\mathrm{j}}^{\mathrm{LF}}-\mathrm{t}_{\mathrm{ij}}
$$

Time reserve of event $R_{j}$ is the time difference between the latest completion of all the preceding activities, and the earliest start of the activities that immediately follow.

$$
R_{j}=T_{j}^{L F}-T_{j}^{E S}
$$

The time reserve of elementary works Rij shows for how long the duration of this work can be increased in comparison with $t_{i j}$ without increasing the time $T$.

$$
R_{i j}=\min \left(T_{j}^{L F}-T_{j}^{E S}-t_{i j}\right)
$$

The system of risk quantitative assessments in logistics provides several approaches to assessing the risk of the expected business result.

Regarding the classical approach to risk assessment in logistics systems, a statistical approach can be used [9]. Suppose that for some one decision (event) in the field of logistics it is possible to estimate the magnitude of undesirable consequences, expressed under different conditions of its (decision) implementation, and the probability of their occurrence, the risk can be estimated as the expected return :

$$
E\left(R_{i}\right)=\sum_{i=1}^{n} p_{i} \cdot x_{i}
$$

where $E\left(R_{i}\right)$ is the magnitude of the risk in logistics (the expected return);

$x_{i}$ - the magnitude (volume) of undesirable consequences in the $i$ conditions of the decision,

$X=\left\{x_{1}, x_{2}, \ldots, x_{i}\right\}$ - the investigated discrete random variable corresponding to the undesirable consequences of the decision;

$p_{i}$ - the probability of undesirable consequences in the $\mathrm{i}$-th conditions of the solution

$P=\left\{p_{1}, p_{2}, \ldots, p_{i}\right\}$ - the distribution of probabilities of possible values of a random variable.

The expected return is a generalized quantitative characteristic and does not allow to make a decision in favor of any variant. For the final decision it is necessary to measure fluctuations of indicators, i.e. to define a degree of fluctuation of a possible result. Fluctuations of the possible result are the degree of deviation of the expected value from the average value. To determine it, usually calculate the variance (variation), or standard deviation:

The standard deviation:

$$
D(X)=\sum_{i=1}^{n} p_{i} \cdot\left(x_{i}-E(R)\right)^{2}
$$




$$
\sigma(X)=\sqrt{D(x)}
$$

It is believed that the greater value of the variance (or standard deviation), the greater degree of risk. In assessing the risk in logistics, we can also use semivariation and other coefficients, the calculation formulas of which are given, in particular in [10].

\section{Practical Part}

\section{Session 1}

TNT Express Company is one of the leaders in the international industry of express delivery of documents, parcels and corporate goods in Ukraine.

The following is a qualitative risk analysis of TNT Express.

At the stage of "receipt of goods " the following risks are possible:

- receiving damaged goods;

- partial delivery of goods;

- loss of goods.

At the stage of goods handling by the enterprise the following risks are possible:

- time of delay of customs clearance of cargo for a longer period;

- impossibility to obtain permits for customs clearance;

- ban on imports of certain types of goods.

At the stage of "delivery of goods" the following risks may arise:

- reluctance of the recipient to pay customs duties and customs clearance services;

- impossibility of delivery of goods due to incorrectly specified address of the consignee in the accompanying documents;

- traffic accident

In addition, all factors that affect the degree of risk can be divided into two groups:

Objective factors include those that do not depend directly on TNT Express and its managers:

- inflation,

- competition,

- political and economic crises,

- duties,

- the presence of the most favored nation treatment,

- possible work in the zone of free economic entrepreneurship.

Subjective factors include those that characterize the subject of decision-making (directly managers and TNT Express Company):

- production potential,

- technological support,

- level of subject and technological specialization,

- labor organization,

- degree of cooperative relations,

- level of safety,

- the level of competence and intellectual potential of the decision-maker,

- choice of type of contracts with the investor or the customer.

\section{Session 2}

Let's consider the main characteristics of the complex of works and transportation TNT-Express company, as a complex work that unfolds over time, and consists of set simpler and elementary work.

We allocated constituent elements for construction of a logistic network (fig. $1(a, b)$ ):

a1 - country of departure;

a2 - sorting center in Belgium;

a3 - sorting center in Poland;

a4 - Boryspil airport;

a5 - composition of the customs control zone (CMS); 
a6 - the composition of the enterprise;

a7 - delivery across Kyiv;

a8 - delivery across Ukraine;

a9 - special service.

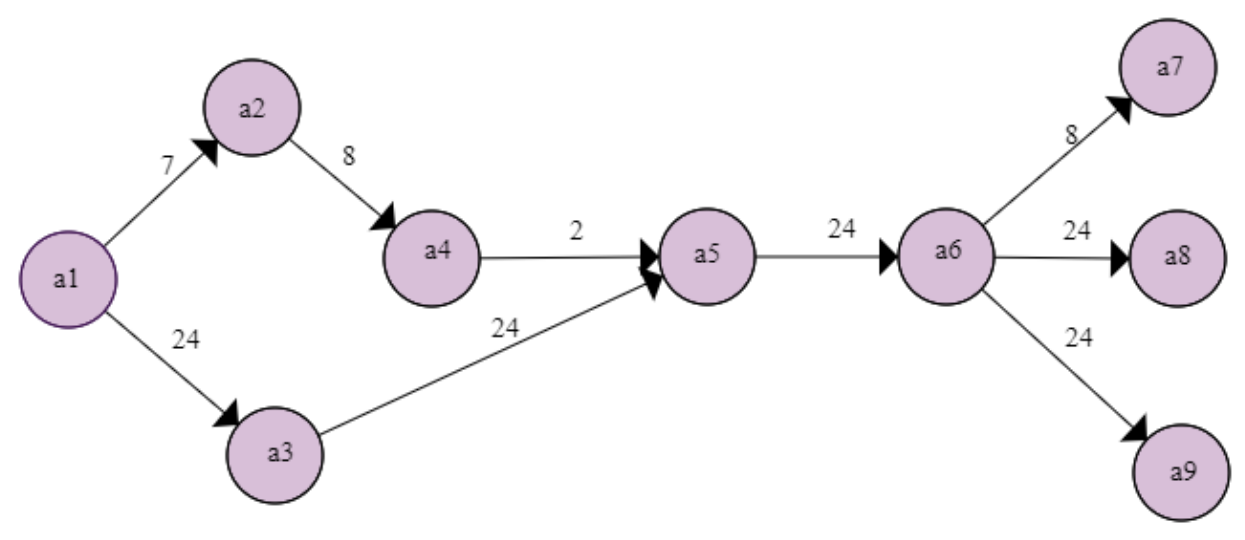

a) customs clearance time 24 hours

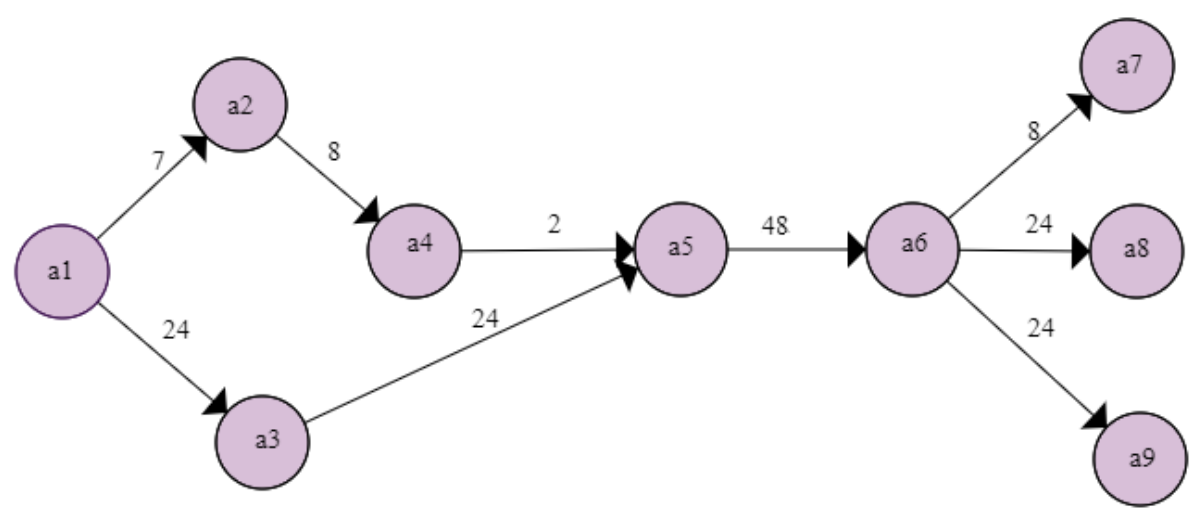

b) customs clearance time 48 hours.

Figure. 1. Network plan of transportation X-Express company

The time analysis is performed according to the following equations:

a) customs clearance time 24 hours:

Earliest starting time of activity

$T_{1}^{E S}=0$

$T_{2}^{E S}=T_{1}^{E S}+t_{1,2}=0+7=7$

$T_{3}^{E F}=T_{2}^{E S}+t_{1,3}=0+24=24$

$T_{4}^{E S}=T_{3}^{E S}+t_{2,4}=7+8=15$

$T_{5}^{E S}=\max \left(T_{4}^{E S}+t_{4,5} ; T_{3}^{E S}+t_{3,5}\right)=\max (17 ; 48)=48$

$T_{6}^{E S}=T_{5}^{E S}+t_{5,6}=48+24=72$

$T_{7}^{E S}=T_{6}^{E S}+t_{6,7}=72+8=80$

$T_{8}^{E S}=T_{7}^{E S}+t_{6,8}=72+24=96$

$T_{9}^{E S}=T_{8}^{E S}+t_{6,9}=72+24=96$

Latest starting time of activity

$T_{9}^{L S}=96$

$T_{8}^{L S}=96$

$T_{7}^{L S}=80$

$T_{6}^{L S}=\min (72 ; 72 ; 72)=72$ 


$$
\begin{aligned}
& T_{5}^{L S}=72-48=24 \\
& T_{4}^{L S}=48-15=33 \\
& T_{3}^{L F}=48-24=24 \\
& T_{2}^{L S}=33-7=26 \\
& T_{1}^{L S}=\min (0 ; 2)=0
\end{aligned}
$$

Time reserve of event $R_{j}$

$$
\begin{array}{ll}
R_{1}=0 & R_{5}=-24 \\
R_{2}=19 & R_{6}=0 \\
R_{3}=0 & R_{7}=0 \\
R_{4}=18 & R_{8}=0 \\
& R_{9}=0
\end{array}
$$

The calculated indicators can be represented by the following Network diagram (fig. 2):

in the right sector - the earliest finish time of activity;

in the left sector - the latest finish time of activity;

in the upper sector - time reserve of event;

in the lower sector - critical activity.

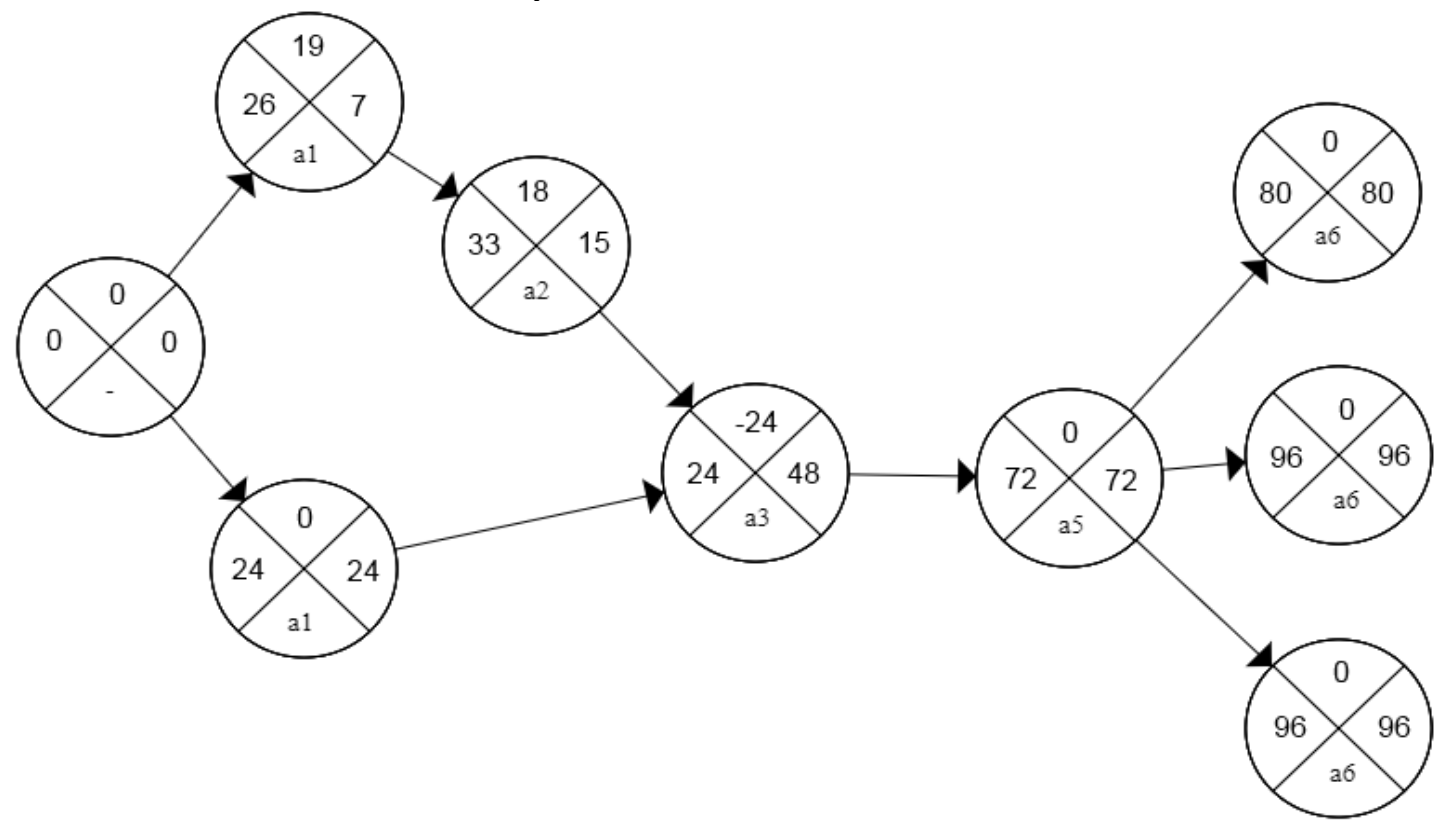

Figure. 2. Network diagram of complex work of customs clearance time 24 hours

The analysis of this network diagram shows that at the stage of work a5 - customs clearance of goods, there is a problem of insufficient amount of time (-24 hours), which will cause a high risk of disruption of the whole complex of works.

Therefore, to prevent logistical risk, more time (for example, 48 hours) should be allocated for customs clearance of goods.

b) customs clearance time 48 hours:

Earliest starting time of activity

$$
\begin{aligned}
& T_{1}^{E S}=0 \\
& T_{2}^{E S}=T_{1}^{E S}+t_{1,2}=0+7=7 \\
& T_{3}^{E F}=T_{2}^{E S}+t_{1,3}=0+24=24 \\
& T_{4}^{E S}=T_{3}^{E S}+t_{2,4}=7+8=15
\end{aligned}
$$




$$
\begin{aligned}
& T_{5}^{E S}=\max \left(T_{4}^{E S}+t_{4,5} ; T_{3}^{E S}+t_{3,5}\right)=\max (17 ; 48)=48 \\
& T_{6}^{E S}=T_{5}^{E S}+t_{5,6}=48+48=96 \\
& T_{7}^{E S}=T_{6}^{E S}+t_{6,7}=96+8=104 \\
& T_{8}^{E S}=T_{7}^{E S}+t_{6,8}=96+24=120 \\
& T_{9}^{E S}=T_{8}^{E S}+t_{6,9}=96+24=120 \\
& \text { Latest starting time of activity } \\
& T_{9}^{L S}=120 \\
& T_{8}^{L S}=120 \\
& T_{7}^{L S}=104 \\
& T_{6}^{L S}=\min (96 ; 96 ; 96)=96 \\
& T_{5}^{L S}=96-48=48 \\
& T_{4}^{L S}=48-15=33 \\
& T_{3}^{L F}=48-24=24 \\
& T_{2}^{L S}=33-7=26 \\
& T_{1}^{L S}=\min (0 ; 2)=0 \\
& \text { Time reserve of event } R_{j} \\
& \begin{array}{ll}
R_{1}=0 & R_{5}=0 \\
R_{2}=19 & R_{6}=0 \\
R_{3}=0 & R_{7}=0 \\
R_{4}=18 & R_{8}=0 \\
& R_{9}=0
\end{array}
\end{aligned}
$$

The calculated indicators can be represented by the following Network diagram (fig. 3):

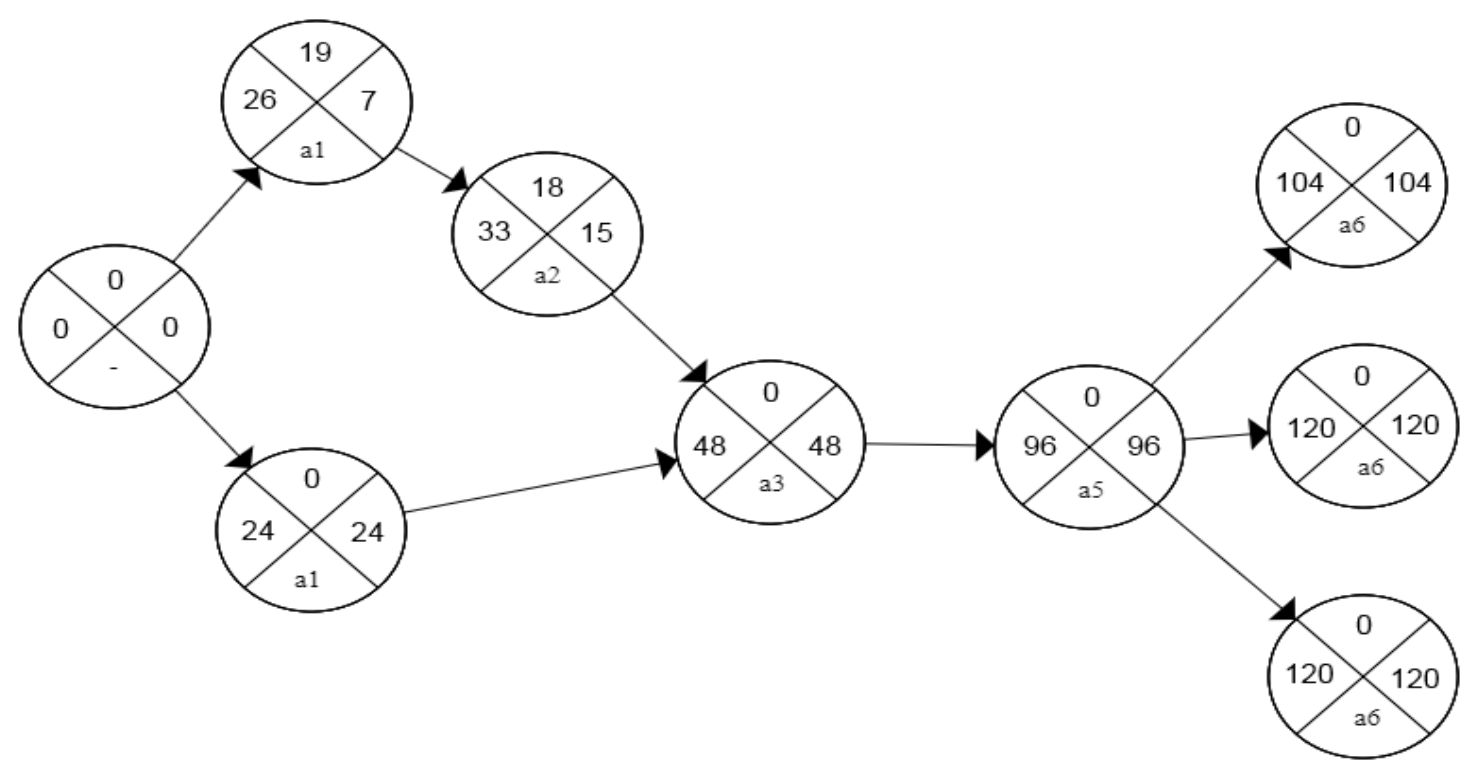

Figure. 3. Network diagram of complex work of customs clearance time 48 hours

The analysis of this network diagram shows that, indeed, to prevent a high risk for customs clearance of goods should be allocated more time (48 hours).

\section{Session 3}

The company has the opportunity to open new flights: Kiev-Novovolynsk or Kiev-Mariupol (table 2). The first option: profit with an average value of 23 thousand UAH ranges from 12 to 24 thousand UAH. The probability of obtaining the minimum profit is $15 \%$, the maximum $-20 \%$. 
The second option: profit at an average value of 18 thousand UAH. It ranges from 14 to 20 thousand UAH. The probability of obtaining a minimum profit is $30 \%$, the maximum $-25 \%$.

The company was faced with a choice of which of the flights would be the most rational for the company.

Table 2

\begin{tabular}{|c|c|c|c|c|}
\hline \multirow{2}{*}{ Profit } & \multicolumn{2}{|c|}{ Kiev-Novovolynsk } & \multicolumn{2}{c|}{ Kiev-Mariupol } \\
\cline { 2 - 5 } & $\begin{array}{c}\text { (in thousands), } \\
\text { UAH }\end{array}$ & probability & $\begin{array}{c}\text { (in thousands), } \\
\text { UAH }\end{array}$ & probability \\
\hline minimum & 12 & 0.15 & 14 & 0.3 \\
\hline average & 23 & 0.65 & 18 & 0.45 \\
\hline maximum & 24 & 0.2 & 20 & 0.25 \\
\hline
\end{tabular}

Calculation of the system of quantitative assessments of effectiveness and risk for the first option:

$$
\begin{gathered}
M_{1}^{+}=12 \cdot 0.15+2 \cdot \cdot 0.65+24 \cdot 0.20=21,55 \\
S V_{1}^{-}=0.15 \cdot(12-21.55)^{2}=13.68 \\
C S V_{1}=\frac{3.69}{21.55}=0,17
\end{gathered}
$$

Calculation of the system of quantitative assessments of effectiveness and risk for the second option:

$$
\begin{gathered}
M_{2}^{+}=14 \cdot 0.3+18 \cdot 0.45+20 \cdot 0.25=17.3 \\
S V_{2}^{-}=0.25 \cdot(14-17.3)^{2}=2.72 \\
C S V_{2}=\frac{1.65}{17.3}=0,095
\end{gathered}
$$

Evaluating these alternatives, we see that the first option is better in terms of future projected expected returns, but the riskiness of the first option is also almost twice as high.

When choosing a rational option, the coefficient of semi-variation should be used as a kind of compromise between efficiency and risk. Therefore, the management of the company as a subject of decision-making should prefer the second option.

- opening of a new flight Kyiv - Mariupol.

Conclusions. Features of the modern external environment - such as variability, multifactoriality, informatization pose new challenges for logistics. Effective logistics risk management at the enterprise is a promising source for strengthening competitive advantages and reducing costs. Logistics helps to find and implement the optimal ratio of costs, inventory and quality of service. To do this, multivariate calculations are performed, the optimal of which is the one that provides the greatest benefit to the system as a whole with the lowest cost, i.e. with the least risk. One of the methods of cost management is network planning, which can be used to identify reserves to reduce the total duration of the logistics cycle. Network planning has a number of advantages: provides clarity of technological sequence of works; allows you to make operational and current plans, as well as predict complex processes; allows you to identify hidden resources of time and material resources during production processes.

Thus, competent risk management in logistics is important for the company and allows you to avoid or minimize risks, reduce costs from the risks taken, transfer responsibility for risks to their partners, increase the company's profits from activities in international markets.

\section{Джерела та література}

1. Christopher, M. Logistics and Supply Chain Management. - 4th Edition. Pearson Education,. 2011. 276 p.

2. Fahimnia, B. and Molaei, R. and Ebrahimi, M. Integration in Logistics Planning and Optimization. (Logistics Operations and Management), 2011. pp $371-391$

https://doi.org/10.1016/B978-0-12-385202-1.00018-9

3. Rand, G.K., Tavares, L.V. Network planning. In: Gass S.I., Harris C.M. (eds) Encyclopedia of Operations Research and Management Science. Springer, New York, NY., 2001 
https://doi.org/10.1007/1-4020-0611-X_665

4. Mašće I, Jurišić, Romaldo Singolo Ino 2018 Network Planning Method in Optimizing Vessel Utilization Laytime Calculation NAŠE MORE: znanstveni časopis za more i pomorstvo, Vol. 65 No. 3,. pp. 146-150

https://doi.org/10.17818/NM/2018/3.3

5. Alper, Sayin \& Tekin, Mahmut. Risk management in logistics sampling of risk components, 2017.

URL:https://www.researchgate.net/publication/321275275_RISK_MANAGEMENT_IN_LOGISTICS_SAMPLI NG_OF_RISK_COMPONENTS

6. Dias, G. C., Hernandez, C. T., and Oliveira, U. R. Supply chain risk management and risk ranking in the automotive industry. Gestão \& Produção, 27(1), e3800., 2020

https://doi.org/10.1590/0104-530X3800-20

7. Завитій О.П, Дідоренко Т.В., Кондрюк Л. Логістичні витрати виробничих підприємств як об'єкти обліку та контролю. Інститут бухгалтерського обліку, контроль та аналіз в умовах глобалізації. 2019. №1-2. С. 49-73.

8. Chukurna O. P. New approaches to the classification of logistics costs of industrial enterprises in the conditions of globalization [Електронний ресурс] Економіка: реалії часу. Науковий журнал. - 2016. - № 3 (25). C. 105-112. URL:: http://economics.opu.ua/files/archive/2016/n3.html

9. Кмитюк Т.Л., Скіцько В.І. Концептуальні аспекти моделювання та управління ризиком цифрової трансформації. Проблеми системного підходу в економіці. Видавничий дім «Гельветика» 2019. - Випуск 6(74) Частина 3. - С.163-170

https://doi.org/10.32782/2520-2200/2019-6-71

10. Вітлінський В.В., Великоіваненко Г.І. Ризикологія в економіці та підприємництві: монографія. Київ: КНЕУ. 2004. 480c.,

\section{References}

1. Christopher, M. (2011) Logistics and Supply Chain Management. - 4th Edition. Pearson Education,. 276. [in English].

2. Fahimnia, B. and Molaei, R. and Ebrahimi, M. (2011). Integration in Logistics Planning and Optimization.

Logistics Operations and Management, pp $371-391$

https://doi.org/10.1016/B978-0-12-385202-1.00018-9 [in English].

3. Rand, G.K., Tavares, L.V. (2001) Network planning. In: Gass S.I., Harris C.M. (eds) Encyclopedia of Operations Research and Management Science. Springer, New York, NY.

https://doi.org/10.1007/1-4020-0611-X 665 [in English].

4. Mašće I, Jurišić, Romaldo Singolo Ino 2018 Network Planning Method in Optimizing Vessel Utilization Laytime Calculation NAS̆E MORE: znanstveni časopis za more i pomorstvo, Vol. 65 No. 3,. pp. 146-150

https://doi.org/10.17818/NM/2018/3.3 [in English].

5. Alper, Sayin \& Tekin, Mahmut. (2017). Risk management in logistics sampling of risk components. Retrieved from:

https://www.researchgate.net/publication/321275275_RISK_MANAGEMENT_IN_LOGISTICS_SAMPLING_OF_RI SK_COMPONENTS [in English].

6. Dias, G. C., Hernandez, C. T., and Oliveira, U. R. (2020) Supply chain risk management and risk ranking in the automotive industry. Gestão \& Produção, 27(1), e3800.

https://doi.org/10.1590/0104-530X3800-20 [in English].

7. Zavytiy, O., Didorenk, T., Kondriuk, L. (2019) Logistic costs of manufacturing enterprises as objects of accounting and control. The institute of accounting, control and analysis in the globalization circumstances. International scientific journal. Issue 1-2. pp. 49-73.

https://doi.org/10.35774/ibo2019.01.049 [in Ukraine].

8. Chukurna, O.P. (2016) New approaches to the classification of logistics costs of industrial enterprises in the conditions of globalization. Economics: time realities. Scientific journal, 3 (25), 105-112. Retrieved from : :http://economics.opu.ua/files/archive/2016/n3.html [in English].

9. Kmytiuk, T., Skitsko, V. (2019) Conceptual aspects of modeling and digital transformation risk management. Problems of system approach in economy, 6 (74), pp. 163-169

https://doi.org/10.32782/2520-2200/2019-6-71 [in Ukraine].

10. Vitlinskyi V.V., Velykoivanenko H.I. (2004) Riskology in Economics and Entrepreneurship. Kyiv: KNEU. 480 p. [in Ukraine].

Стаття надійшла до редакції 14.02.2020 р. 